\title{
SINGULARITY OF SUSTAINABLE TAXATION IN AGRICULTURE
}

Erika BESUSPARIENE், Faculty of Economics and Management, Aleksandras Stulginskis University. Studentu str. 11, Akademija, Kaunas dstr., Lithuania, erika.besuspariene@gmail.com

\begin{abstract}
Agricultural sector is different from industrial or service sectors due to its specific functions, i.e. food function, social function, economic situation on country growth function, environmental function. These functions of agricultural sector include three dimensions (economic, social, environmental), which are closely connected with the conception of sustainable development. Therefore, the taxation system of agricultural sector has been orientated to sustainability. The research direction of sustainable taxation is relevant. This research direction leads to opportunities to find the sustainable taxation system effect to the sustainable development of agriculture. The paper aims at disclosing the singularity of sustainable taxation in agriculture. To investigate the theoretical aspect of the specificity of agricultural business in the context of taxation and singularity of sustainable taxation, systemic analysis and synthesis of theoretical insights of foreign and local scientific literature as well as the methods of induction and deduction have been applied. Theoretical research results helped to identify singularity of sustainable taxation in agriculture, which encompasses three dimensions (economic, social, environmental) with different characteristics. This taxation system contributes to the goals of the development of sustainable agriculture.
\end{abstract}

Keywords: agriculture, sustainable agriculture, sustainable taxation, taxation.

\section{INTRODUCTION}

Researchers reveal various assumptions for sustainable taxation (Common, 1992; Skea, Nishioka, 2008; Stahel, 2013; Schratzenstaller, 2016), thus, in order to create a sustainable taxation system, it is important to assess the government policy as well as the needs of business and society (Skea, Nishioka, 2008). The agricultural activity can be distinguished by its singularity that is determined by the seasonality of works, government regulations, work with biological assets and the dependence on environmental conditions (Girdziute, Slavickiene, 2011). Therefore, in many countries, due to the specifics of agriculture, different means of taxation are applied. The role of the agricultural sector is significant in meeting the needs of the society and implementing the government policy. In order to reach the aims of the government and common agricultural policy, it is essential to focus on the development of the competitiveness and sustainability of the agricultural sector by applying various means (European commission, 2013). Taxation is one of the main tools to develop sustainability of the agricultural sector. With the purpose of establishing sustainable taxation for the agricultural sector, it is essential to take into account its singularity and the main principles of sustainability. Schratzenstaller (2016) distinguished dimensions of sustainable taxation system (economic, social, environmental) that correspond to the functions of the agricultural sector (food function, social function, economic situation on country growth function, environmental function). Therefore, to reach the aims of the common agricultural policy, countries have to implement the reform of a sustainable taxation system. There is a lack of detailed research on the directions of sustainable taxation of agriculture. Therefore, it is necessary to assess which challenges of agriculture could be solved by the introduction of sustainable taxation approach. Today, it is not known exactly how sustainable taxation would improve development of agriculture. The relevance of this research shows various discussions about sustainable taxation (OECD, 2018; ICC, 2018; European Union, 2017; Krenek, Schratzenstaller, 2017).

The problem of research - what are the aims of sustainable taxation and how could sustainable taxation system contributes to the sustainable development in agriculture?

The aim of this research is to reveal the peculiarities of sustainable taxation in agriculture. In order to reach this aim, the following objectives have been set out:

1. to theoretically validate the singularity of agriculture in the context of taxation;

2. to analyse the essence of sustainable taxation;

3. to reveal the peculiarities of sustainable taxation in agriculture.

Research methodology. In the research, the singularity of agricultural business in the context of taxation has been identified, regulations of sustainable taxation have been summarised and dimensions of sustainable taxation in agriculture

Copyright (C) 2017 The Authors. Published by Aleksandras Stulginskis University. This is an open-access article distributed under the terms of the Creative Commons Attribution License (CC-BY 4.0), which permits unrestricted use, distribution, and reproduction in any medium, provided the original author and source are credited. 
have been specified. In order to assess the correspondence of the agricultural business taxation with the criteria of sustainable taxation, various scientific literatures have been analysed.

\section{RESEARCH FINDINGS}

\section{The specifics of agricultural business in the context of taxation}

The applied taxation systems are closely connected to the pace of the economic growth of countries (Engen, Skinner, 1996; Myles, 2000; Myles 2009; Hatfield, 2015). The agricultural sector is identified as one of the most significant sectors that contribute to the economic growth (Johnston, Mellor, 1961; Gollin, Parente, Rogerson, 2002). Researchers indicate the importance of this sector to the economic development as well as the singularity of agricultural business. Due to its singularity and the significant contribution of the agricultural sector to the economy of countries, various political decisions, dealing with different taxation of the agricultural business have been made in countries all over the world. The agricultural sector stands in contrast to the industrial and service sectors (Lamb, 1994; Brain, Deac, 2010), thus, the taxation systems applied to agricultural business differ from those applied to other businesses (Leibus, Irmeja, 2014; Mukhtar, Nasim, 2016). Therefore, in order to reach the economic growth of agriculture, effective policies should be applied that stimulate agriculture. According to the existing agricultural policy of the European Union and the new policy that will be implemented after 2020 (European commission, 2013; European Uni on, 2016), economic questions are essential and the agricultural sector is viewed as a strategic sector, which ought to keep contributing to the growth of the European economy. Researchers (Mukhtar, Nasim, 2016; Leibus, Irmeja, 2014) state that the taxation of agricultural business has to be different, as in this way it could have a positive impact on the economy of the country. However, inadequate political decisions related to the taxation system may negatively affect the tendencies of agricultural business. Inadequately selected taxation of agricultural business and remaining old provisions of taxation can significantly impact the economic situation of countries as well as the declining situation of agricultural business (Butcher, Xu, 2016; Mukhtar, Nasim, 2016). According to researcher Lamb (1994), due to its singularity the agricultural business has to be completely excluded from the economy, as its nature differs from the industrial sector. In the agricultural sector, the priority is given to the activity of cultural agriculture and cultivation of land, whereas the produced food is seen as the result of this activity. On the other hand, Lamb (1994) confirms that agriculture is a part of economy. However, it is necessary to find ways to make the land available for the agriculture in small expenditures or for free as otherwise agricultural business cannot sufficiently use nature and compete in the fields of economics and industry.

The agricultural business is important not only economically, but also socially. Thus, different elements of the taxation system are significant in the social context. Social significance of agriculture is demonstrated by various scientific researches (Allen, Van Dusen, Lundy, Gliessman, 1991; Alston, 2004; Vanclay, 2004; Foti, Scuderi, Timpanaro, 2013). The social aspect is one of the parts that create the singularity of the agricultural business; it contributes to the benefits created by the society, such as the stimulation of the vitality and prosperity of the rural area, establishment of the rural values, development of rural management and guarantee of poverty reduction and low-cost food. Poverty reduction is one of the main political aims in developing countries. Therefore, according to Bresciani, Valdés (2007) the input created by the agricultural sector to reduce poverty is becoming more significant than the economic benefit of this sector. One of the exclusive features of the agricultural business, related to the fight against world poverty, is to ensure the demand of low-cost food, especially in countries with high population; it can be done by applying different taxation rules for the agricultural business (Zhong, Turvey, Zhang, Xu, 2011). Researchers (Allen, Van Dusen, Lundy, Gliessman, 1991; Alston, 2004; Vanclay, 2004) distinguish an important connection between the agricultural business and society by emphasising that the decisions of the production of the agricultural business depend on the decisions of the consumers. Nevertheless, the agricultural impact on the society due to the production decisions of farmers is also important. All of this conditions the variety and quality of available food products, whereas the size of the farm and the employed technologies are connected to the economic and social power of rural communities. The goals of the agricultural policy of the European Union for 20142020 are to maintain the high quality production in agriculture and to provide safe and healthy food products for a reasonable price (European Commission, 2013). In the new guidelines for the agricultural policy after 2020, it is also proposed to take the concerns of the consumers over the quality of the processes and grown products into account, thus, the demand for healthy food has to be implemented (European Union, 2016). Unfortunately, some of the social outcomes remain invalid and are not being solved. For instance, the strategy of ecological agriculture is important and is usually supported; however, people with low income are not able to afford ecological products, hence, they are prevented from buying these products that have fewer residues of pesticides (Allen, Van Dusen, Lundy, Gliessman, 1991). Properly adjusted taxation systems can contribute to the aims of guaranteeing food and its safety; however, improperly established tax reliefs or other taxation instruments cannot assure value-added agricultural business or possible benefits for the consumers.

It is important to acknowledge the fact that farming is not a technical activity, but rather a social and cultural practice, therefore farming becomes a lifestyle. The community of farmers is not homogeneous and consists of the rich and the poor, large and small scale, young and old farmers that are prone to applying new ideas and keeping the old methods. It shows that the problems are not homogeneous as well, therefore there is no single applicable solution and single strategy (Vanclay, 2004). However, inadequate political and taxation solutions adopted in countries predict an uncertain future for the rural communities and family farms. Family farms are important as a predominant form of social relations in agricultural manufacturing and rural communities (Alston, 2004). The survival of agriculture depends on the survival viable rural communities (Vanclay, 2004). In the context of aging population, the renewal and survival of agricultural activity in rural 
areas is extremely important, therefore one of the priority issues in the European Union Agricultural Policy for 2014-2020 is employment (European Commission, 2013). The jobs created in agricultural business are crucial to the survival of rural areas. Therefore, the issues related to promotion of the prosperity of rural areas and the value chain of rural development play a key role in creating a new European Union Agricultural Policy after 2020 (European Union, 2016). Different means of agricultural business taxation system may help keeping workers, attracting new people to agricultural businesses and rural areas, which would ensure the prosperity of rural area and the survival of rural communities. The criteria that are usually applicable in taxation systems are not suitable to the classification of agricultural business. According to Vanclay (2004), farmers are to be grouped by subcultural groupings, i.e. the style of farming. The main aspect of social understanding is that the agricultural variety is to be understood not only from a physical or structural, but also from a social point of view. The social understanding of agriculture will help to promote sustainable agriculture.

It is important to note the negative influence that the society has on agricultural business. Society exercises significant influence on agriculture due to lost valuable agricultural land, urbanisation processes, increased land value, city pollution, decreasing crop productivity (Allen, Van Dusen, Lundy, Gliessman, 1991). Such negative influence of the society can also be solved by using different taxation means, especially in terms of agricultural taxation. Apart from the influence of consumers and community, international agriculture is important as well. Social and economic conditions of other countries, global food supply may severely influence the vitality of agriculture in local regions (Allen, Van Dusen, Lundy, Gliessman, 1991). The mission of social agriculture is to guarantee that both political and economic entities were familiarised with new practices, based on true participation, solidarity, mutual understanding and responsible use of resources and novelties, which, together with different societal groups, aim at increasing the social richness of rural and suburban territories, communities, institutions and agriculture (Hausmann et al., 2010, cited Foti, Scuderi, Timpanaro, 2013).

Various environmental taxes introduced in taxation systems are important in the context of environmental pollution and climate change. The specificity of agricultural business production is closely linked to these issues. The importance of agricultural business and environmental protection has been demonstrated by a great number of scientific research (Allen, Van Dusen, Lundy, Gliessman, 1991; Horrigan, Lawrence, Walker, 2002). The practice of agricultural businesses in developing irrigation systems and using particular chemicals often has a negative impact on the environment due to the killing of wild animals, pesticide residues in drinking water, soil erosion, and the depletion of underground water. An important step in solving these problems is the use of environmentally friendly raw materials (Allen, Van Dusen, Lundy, Gliessman, 1991). The development of new farming methods should be directed towards systems that are more sustainable and oriented to the protection of natural resources (European Union, 2016). Taxation affects people's decisions, and agriculture is no exception (Veen, Meulen, Bommel, Doorneweert, 2007). A sustainable agricultural movement, one of the goals of which is to create farming systems that would mitigate or eliminate environmental damage caused by industrial agriculture, is of great significance as well. It should be noted that natural resources are limited, thus the limits of economic growth shall be acknowledged and fair distribution of resources should be promoted. Thus, more attention is paid to longterm goals such as preserving soil, biodiversity and rural communities than short-term goals such as profit-making (Horrigan, Lawrence, Walker, 2002). Various sustainability programmes are of great importance in this context as they aim at finding solutions to common problems by changing production practices (Allen, Van Dusen, Lundy, Gliessman, 1991). Therefore, agriculture starts playing an important role in tackling climate change (European Union, 2016). Different taxation measures of agricultural business may help changing the old established practices that promote environmental protection.

The analysis of scientific literature (Table 1) on the specificity of agricultural business showed that agricultural business is different from other industrial and service sectors, as evidenced by the specific differences in different dimensions (economic, social, environmental). Green (1999) argues that the idea that agriculture is different from all other industries helps to explain the domestic policies of many countries and different taxation systems that they apply. Research on taxation began more than 60 years ago, however, many economists have ignored the agricultural sector and were far from realising that the agricultural sector is very different from other industrial or service sectors.

\section{Theoretical analysis of sustainable taxation}

In light of current topical issues, in the context of taxation agricultural business should be oriented towards sustainability as well. The fact that the topic of sustainable taxation system has been studied by various scientists (Common, 1992; Skea, Nishioka, 2008; Stahel, 2011; Stahel, 2013; Stancil, 2013; Murray, Oliver, Wyatt, 2014; Schratzenstaller, 2016), who indicates the importance of sustainable taxation system and its necessity in the country. One of the principles of sustainable taxation is to prevent the influence of undesirable activities and compensate the desired changes (Stahel, 2011; Stahel, 2013). Stahel (2013) believes that the taxes on renewable resources, including work and human resources, are counterproductive and should be refused in the context of sustainable economics. According to Common (1992), generally the optimal taxation, the objective function of which is to minimise the deadweight burden and assess the preferences of individual consumers, is known. However, having imposed the sustainability limitations on the optimal taxation, it is not known how these limitations are to be modelled. Without the minimalization of the deadweight burden, the state revenue is to be ensured. According to Stahel (2013), the state revenue, which is lost when the taxation of renewable resources is rejected, may be compensated by imposing taxes on the consumption of nonrenewable resources, i.e. material, energy, waste and emissions. Such taxation system would promote circular economy. The importance of circular economy that can be established with the help of sustainable taxation raises more and more scholarly discussions. Stahel (2013) claims that the transition to sustainable taxation is a very important factor that provides an opportunity to enrich circular economy in the national economy by re-use, repair, recycling, etc. 
Table 1. Specificity of the agricultural sector

\begin{tabular}{|c|c|c|}
\hline Author & Specificity of the agricultural sector & $\begin{array}{l}\text { Taxation system } \\
\text { dimensions }\end{array}$ \\
\hline Bardhan (1961) & $\begin{array}{l}\text { In some countries, taxes paid by agricultural business account for more than } 50 \\
\text { per cent of total state revenue. }\end{array}$ & Economic \\
\hline Raj (1973) & $\begin{array}{l}\text { Health taxes are important as due to the specificity of agricultural production, farmers } \\
\text { may get injured. }\end{array}$ & Social \\
\hline $\begin{array}{l}\text { Chaudhry, Khan } \\
\text { (1999) }\end{array}$ & $\begin{array}{l}\text { The intensity of land use depends on the size of a farm, however, even large farms may } \\
\text { use the land inefficiently, thus, higher land taxes may encourage farmers to use land } \\
\text { more efficiently and more intensively. }\end{array}$ & Environmental \\
\hline $\begin{array}{l}\text { Chaudhry, Khan } \\
\text { (1999) }\end{array}$ & $\begin{array}{l}\text { Taxation system of agricultural income is beneficial in terms of fair distribution of } \\
\text { income, poverty reduction and better nutrition in rural areas. }\end{array}$ & $\begin{array}{l}\text { Economic } \\
\text { Social }\end{array}$ \\
\hline Khan (2001) & $\begin{array}{l}\text { The prevailing objective of the taxation of agricultural business is to generate } \\
\text { government revenue and transfer a significant share of the funds from the agricultural } \\
\text { sector to general economy. }\end{array}$ & Economic \\
\hline $\begin{array}{l}\text { Demyanenko, } \\
\text { Zorya (2004) }\end{array}$ & $\begin{array}{l}\text { Farming is not distinguished from other economic activities. Taxation system of farms } \\
\text { has an impact on the country's macroeconomic development via several channels, } \\
\text { most of which are invisible. Agriculture often becomes a hostage of those invisible } \\
\text { effects, as macroeconomic destabilisation affects farms as well. }\end{array}$ & Economic \\
\hline $\begin{array}{l}\text { Ronge, } \quad \text { Wanjala, } \\
\text { Njeru, Ojwang'i } \\
(2005)\end{array}$ & $\begin{array}{l}\text { Agricultural taxation is equivalent to agricultural price policy, which affects farmers' } \\
\text { decisions on investment and production. }\end{array}$ & Economic \\
\hline $\begin{array}{l}\text { Nam, Parsche, } \\
\text { Radulescu, Schöpe } \\
\text { (2007) }\end{array}$ & $\begin{array}{l}\text { The specific method of agricultural production has a negative impact on the } \\
\text { environment due to the use of fertilisers, pesticides and energy. Different countries } \\
\text { have different taxation systems for prevention of environmental pollution. }\end{array}$ & Environmental \\
\hline $\begin{array}{l}\text { Zhong, } \quad \text { Turvey, } \\
\text { Zhang, Xu (2011) }\end{array}$ & $\begin{array}{l}\text { There is a link between taxation and agricultural business productivity; it is one of the } \\
\text { key factors for countries with a high population to ensure low-cost food policy. }\end{array}$ & Social \\
\hline $\begin{array}{l}\text { Ibolya, Kristóf, } \\
\text { Pawlowska-Tyszko } \\
(2014)\end{array}$ & $\begin{array}{l}\text { Inadequate legal decisions regarding the structure of agricultural taxation system may } \\
\text { be disadvantageous, as taxation model may be used by people who are not engaged in } \\
\text { agricultural activities but have bought land for speculation and have used preferential } \\
\text { treatment that was originally intended for farmers. }\end{array}$ & Social \\
\hline Hassen (2016) & $\begin{array}{l}\text { In most developing countries, the government imposes taxes on agricultural income, } \\
\text { however, it is difficult to determine the income of small farmers and individuals. These } \\
\text { difficulties occur due to a large number of low income generation, the absence of } \\
\text { accounting procedures for income taxation, agricultural productivity and profit } \\
\text { fluctuations, and low level of education. }\end{array}$ & $\begin{array}{l}\text { Economic } \\
\text { Social }\end{array}$ \\
\hline
\end{tabular}

As shown in Figure 1, eight sectors, which can be positively influenced by sustainable taxation, are distinguished. As stated by Stahel (2013), exempting the renewable resources from taxes, including work and imposing taxes on nonrenewable resources would accelerate the economic transition from flow to resource optimisation, expand the application of circular economy to new economic subjects and sectors, enhance the advantages of current economic subjects operating in circular economy. Sustainability-oriented taxation system promotes high-quality workforce and allows reducing work costs by sorting used material, while the cost of non-renewable resources increases. Sustainable taxation system should encourage the creation of more efficient materials, which would allow to save money and reduce consumption. Stahel (2013) claims that the research conducted in Denmark, Sweden and United Kingdom showed that the taxes on natural resources reduce the consumption of raw materials.

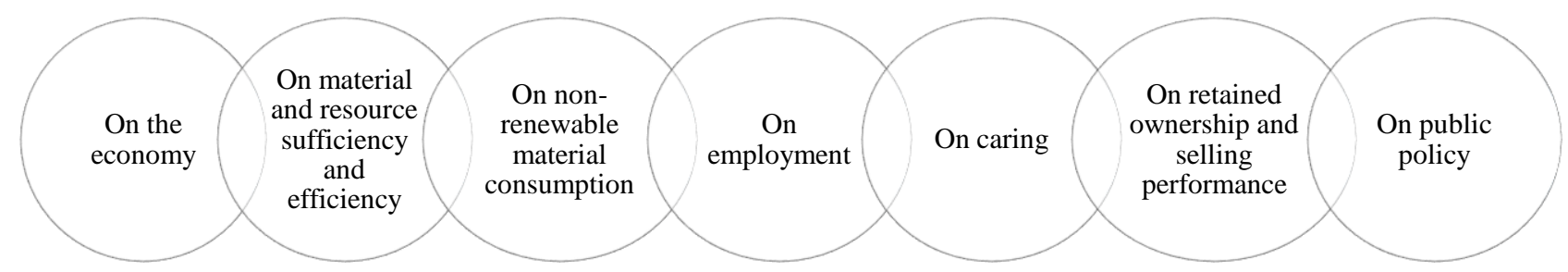

Source:based on Stahel (2013)

Figure 1. Impacts of sustainable taxation

Stahel (2013) claims that in order for the sustainable taxation system affect the above-mentioned fields, the principles of sustainable taxation should be simple. Common (1992) believes that the taxation system that corresponds to the essence of sustainability should:

- Protect the most important environmental resources and processes;

- Encourage saving and investments;

- Focus on investments that would search for the alternatives of environmental resources and processes;

- Not promote the growth of population;

- Promote the equability of generations. 
To create a sustainable tax reform, it is necessary to manage the whole taxation system. The management of the whole taxation system involves a systemic attitude towards tax reform, political, administrative and private sector infrastructure, its consistent growth, compliance with the changing needs of the society. This would allow the system to function and eventually become sustainable (Skea, Nishioka, 2008). Schratzenstaller (2016) has defined the main dimensions of sustainability-oriented taxation system.

As shown in Figure 2, according to Schratzenstaller (2016), the economic dimension of sustainable taxation system is oriented towards the economic growth, to which the agricultural business as well as stability and survival of agricultural business contribute greatly. Social dimension of sustainable taxation system is important when it comes to social inclusion and management. Taking into consideration agricultural business, social inclusion and family farms play a key role in the society's inclusion in rural communities, their management and support of their activities. Environmental dimension of taxation system emphasises four aspects which are important in the taxation of agricultural business, namely, protection of biodiversity and natural resources, fight against pollution and climate change.

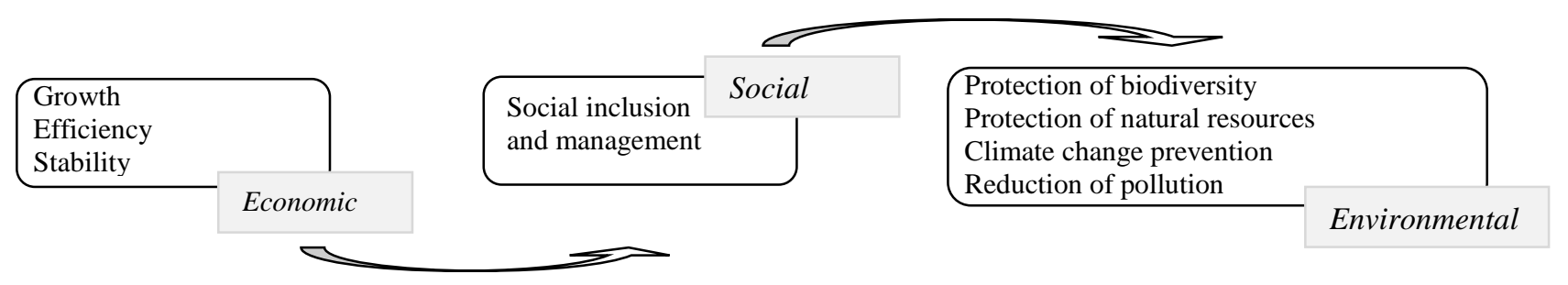

Source: based on Schratzenstaller (2016)

Figure 2. Dimensions of sustainability-oriented taxation system

However, sustainable taxation system is a set of various laws and legal regulations that would have to be amended every time when a country changes its sustainable taxation policy. Therefore, it may cause an inefficiency of global sustainable taxation policy, which in turn can result in legal gaps or distortions. Thus, when aiming towards a global sustainable taxation the following characteristics are to be taken into account: neutrality, universality, coordination, Pigouvian taxation, abolition of subsidies, social equality and visibility (Murray, Oliver, Wyatt, 2014). To reach the goals of sustainable taxation stated by Common (1992) and Schratzenstaller (2016), specific means that would help to achieve this aim are to be implemented. Analysing the problems of sustainability in Japan (large amount of emissions, water quality, amount of carbon dioxide), Skea and Nishioka (2008) claim that the aim of sustainable taxation and sustainable financing is the ability of different partners (citizens, business entities and governmental bodies) to share economic and environmental benefit. In such a case, sustainable taxation would include the following specific means:

- Environmental rules;

- Land use and construction regulations;

- Subsidies for advanced technologies;

- Independent plans of environmental actions;

- Awareness programmes.

The analysis of scholarly literature revealed that the issue of sustainable taxation and the implementation of sustainable taxation system is a relevant topic, however, the procedures of its implementation are rather complex. To implement the principles of sustainable taxation, countries have to take into consideration their legal acts and to predict their amendments. However, it remains the most complex issue. Yet, the fact that scientists have shown the influence of sustainable taxation on different fields encourages countries to search for the best solutions and aim at the implementation of sustainable taxation. According to Novosinskiene (2013), in order to implement a sustainable taxation system, the country's taxes should be harmonious and mutually connected.

\section{RESEARCH RESULTS}

Schratzenstaller (2015) distinguished various types of indicators which could be used for assessment of taxation system sustainability. However, to adapt this assessment for taxation of agriculture it is necessary to determine parts of sustainable taxation system of agriculture. Taking into account taxation dimensions outlined in the article and the specificities of agricultural business in the context of taxation, the peculiarities of sustainable taxation in the agricultural sector may be revealed.

European Union (2016) notes future agriculture challenges are economic prosperity, food security, climate change, resource management, social inclusion and i.e. Therefore, taxation system of agriculture has to contribute to the ensuring enough incomes for agriculture workforce, food security, effective land use, climate changes prevention and i.e. This could be done through various tax instruments, which was disclose in research done by Common (1992), Skea and Nishioka (2008), Stahel (2011), Stahel (2013).

Each dimension of sustainable taxation system and its implementation would ensure the implementation of the goals set for agriculture. Having summarised the results of research carried out by various scientists, a theoretical model of the peculiarities of sustainable taxation in agriculture has been development (Fig. 3). This theoretical model presents the main dimensions of sustainable taxation (economic, social, environmental). 
The development of further research based on the model presented (Fig. 3) could set taxes which could ensure mentioned goals. Poverty reduction could be solved through tax rate which let to ensuring income for agriculture workforce. Family farm taxes could lead preservations of rural communities and ensure enough investment to family farm. Environmental taxes would solve pollutant behaviour and at the same time ensuring biodiversity security and safe food. Today new technology offers new opportunities for agriculture and tax exemption for new technology using could have positive influence for climate changes, agricultural workforce health, and food quality. This allows constructing new design of sustainable tax system of agriculture sector.

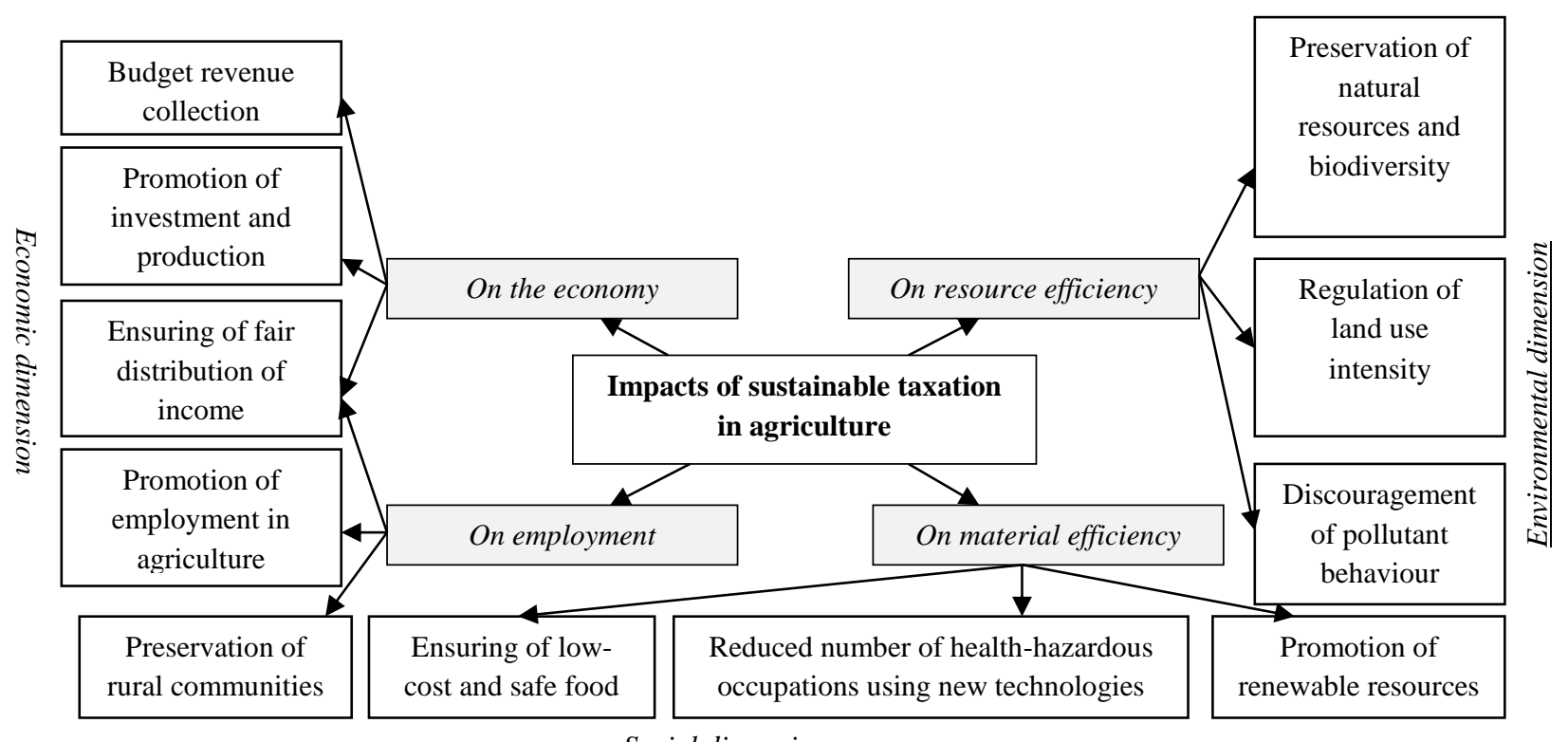

$\underline{\text { Social dimension }}$

Figure 3. Singularity of sustainable taxation in agriculture

If sustainable taxation was implemented in the country, its positive impact would be felt in the country's economy, employment, and efficiency of raw materials and resources. This impact would be felt for several distinct reasons.

The importance of economic dimension. By imposing taxes on agricultural businesses, the government ensures revenue collection in the budget. However, by minimising the tax burden on agricultural businesses, the government could here with encourage greater investment in the development of agricultural activities. In some countries, taxation of farmers is based on the area of the land they own. Such grouping of farmers in the context of taxation may be indicative of an unfair distribution of income, thus, as claimed by Vanclay (2004), farmers could be grouped more rationally according to the farming style. In order to maintain budget revenue from agriculture, the preservation of rural communities should be paid great attention as, according to Vanclay (2004), the survival of agriculture depends on viable rural communities who are the main labour force in the agricultural sector.

The importance of social dimension. Even though rural communities contribute to agricultural business economically, they are also very important from a social perspective. Family farms play an important role in rural communities. According to Vanclay (2004), family farming is not only business, but also social and cultural practice. According to Bresciani, Valdés (2007), agriculture helps solving the issue of poverty. Given the importance of circular economy, agricultural business, searching for more efficient ways to use raw materials, may find ways to offer low-cost and safe food, thus contributing to poverty reduction. It is important to search for new farming methods to protect natural resources (European Union, 2016) as well as people. Fertilisers and pesticides used in agriculture have a negative impact on human health. The use of new technologies can contribute to protecting the health of people working in agriculture and those living in rural areas.

The importance of environmental dimension. The most important objective is an efficient use of resources (including land).The intensity of land use is significant in terms of the preservation of biological diversity, therefore, Chaudhry, Khan (1999) claim that appropriate methods of taxation may encourage farmers to use land more efficiently and intensively. Meanwhile, the negative effects of fertilisers, pesticides and energy on agriculture can be controlled by applying different taxation systems to prevent environmental pollution (Nam, Parsche, Radulescu, Schope, 2007).

\section{CONCLUSION}

1. Agricultural business is specific in terms of taxation since the share of taxes paid by agricultural sector is a significant share of state revenue, which cover state expenditure and may constitute of investment in rural prosperity, viability, knowledge and innovation; there is a link between taxation and agricultural productivity, which promotes greater investment, new production methods, thus contributing to creation of new jobs, cheap food policies, poverty reduction; proper land taxes may prevent speculation in land acquisition, increase the use of land, which determines the state of landscape and biodiversity; the introduction of environmental taxes is an important instrument for controlling pollution 
and climate change; agricultural business distinguishes itself from other business for healthy risks, thus health taxes should be taken into consideration as well.

2. Sustainable development aims at preventing the effects of undesirable activities and compensating for the desired changes. Thus, sustainable taxation is closely related with circular economy, which is based on the principle that raw materials should be used efficiently and repeatedly (recycled, repaired). The objectives of sustainable taxation are to protect resources, promote saving, search for resource substitutes, and promote homogeneity of generations. Sustainable taxation would cover various legal acts related with environmental protection, land use and construction, and awarenessraising programmes. By implementing the conception of sustainable taxation, the positive effect would be felt in economy, employment, more efficient use of raw materials, and the use of renewable resources.

3. The peculiarities of sustainable taxation in agriculture are revealed through three dimensions: economic, social, and environmental. The impact of sustainable taxation on different areas is felt via economics, employability, and efficient use of raw materials and resources. The peculiarities of sustainable taxation in agriculture are as follows: budget revenue collection, promotion of investment and production, ensuring of fair distribution of income, promotion of employment in agriculture, preservation of rural communities, ensuring of low-cost and safe food, reduced number of health-hazardous occupations, promotion of renewable resources, discouragement of pollutant behaviour, regulation of land use intensity, preservation of natural resources and biodiversity.

\section{REFERENCES}

1. Allen, P., Van Dusen, D., Lundy, J., Gliessman, S. 1991. Integrating social, environmental, and economic issues in sustainable agriculture. American Journal of Alternative Agriculture, Vol. 6(1), pp. 34-39. https://doi.org/10.1017/S0889189300003787

2. Alston, M. 2004. Who is down on the farm? Social aspects of Australian agriculture in the 21st century. Agriculture and Human Values, Vol. 21(1), pp. 37-46. https://doi.org/10.1023/B:AHUM.0000014019.84085.59

3. Bardhan, P.K. 1961. Agriculture Inadequately Taxed. The Economic Weekly, Vol. 13(49), pp. 1829-1835.

4. Brain, M., Deac, A.L. 2010. Predisposition to risk farming. Internal Auditing \& Risk Management, Vol. 3(19), pp. 43-46.

5. Butcher, B., Xu, Y. 2016. Chinese tax policy and the promotion of agricultural cooperatives and environmental protection. Available https://www.researchgate.net/profile/Yan Xu30/publication/314152354 Chinese Tax Policy and the Promotion of Agricultu ral_Cooperatives_and_Environmental_protection/links/58b77139a6fdcc2d14d704e7/Chinese-Tax-Policy-and-the-Promotion-ofAgricultural-Cooperatives-and-Environmental-protection.pdf (Accessed on 11/10/2017).

6. Chaudhry, M. G., Khan, M. A. 1999. The Theory and Practice of Agricultural Income Tax in Pakistan and a Viable Solution. The Pakistan Development Review, pp. 757-768.

7. Common, M. 1992. Taxation and sustainability. Review of Marketing and Agricultural Economics, Vol. 60(2), pp. $255-267$.

8. Demyanenko, S., Zorya, S. 2004. Taxation and Ukrainian agriculture. Ukrainian Agriculture-Crisis and Recovery, Shaker Verlag, Aachen, 25-39.

9. Engen, E.M., Skinner, J. 1996. Taxation and economic growth. National Tax Journal, Vol. 49 (4), pp. 617-642. https://doi.org/10.3386/w5826

10. European commission. 2013. Overview of CAP reform 2014-2020. Available at https://ec.europa.eu/agriculture/sites/agriculture/files/policy-perspectives/policy-briefs/05_en.pdf (Accessed on 06/11/2017)

11. European Union. 2016. Cork 2.0 declaration “A Better Life in Rural Areas". Available at https://enrd.ec.europa.eu/sites/enrd/files/cork-declaration en.pdf (Accessed on 06/11/2017).

12. European Union. 2017. Gender equality and taxation in the European Union. Available at https://pdfs.semanticscholar.org/2b1c/35a99efb6aa55c5bc73335370014c24a72ce.pdf (Accessed on 17/02/2018).

13. Foti, N.T., Scuderi, A., Timpanaro, G. 2013. Organic social agriculture: a tool for rural development. Available at https://www.researchgate.net/profile/Giuseppe_Timpanaro/publication/236615829_Organic_social_agriculture_A_tool_for_rural _development/links/004635184b6767a13c000000.pdf (Accessed on 11/11/2017).

14. Girdziute, L., Slavickiene, A. 2011. Agricultural risks and analysis of thier evaluation methods. Management theory and studies for Rural Business and Infrastructure Development, Vol. 3(27), pp. 66-77.

15. Gollin, D., Parente, S., Rogerson, R. (2002). The role of agriculture in development. The American Economic Review, 92(2), 160164. https://doi.org/10.1257/000282802320189177

16. Green, R. 1999. The Uruguay Rouond Agreement on Agriculture. Law \& Pol'y Int'l Bus., Vol. 31, 819.

17. Hassen, A.A. 2016. Agricultural taxation and economic growth in Ethiopia. In 2016 AAAE Fifth International Conference, Addis Ababa, Ethiopia (No. 246395). African Association of Agricultural Economists (AAAE). Available at http://ageconsearch.umn.edu/bitstream/246395/2/129.\%20Agricultural\%20tax\%20in\%20Ethiopia.pdf (Accessed on 06/11/2017).

18. Hatfield, J. W. (2015). Federalism, taxation, and economic growth. Journal of Urban Economics, Vol. 87, pp. 114-125. https://doi.org/10.1016/j.jue.2015.01.003

19. Horrigan, L., Lawrence, R.S., Walker, P. 2002. How sustainable agriculture can address the environmental and human health harms of industrial agriculture. Environmental Health Perspectives, Vol. 110(5), pp. 445-456. https://doi.org/10.1289/ehp.02110445

20. Ibolya, L., Kristóf, T., Pawloska-Tyszko, J. 2014. Taxation in the Polish and Hungarian agriculture and health care systems. Research Institute of Agricultural Economics, pp. 77-96.

21. ICC. 2018. Tax and the United Nations Sustainable development goals. Available at https://cdn.iccwbo.org/content/uploads/sites/3/2018/02/icc-position-paper-on-tax-and-the-un-sdgs.pdf (Accessed on 17/02/2018). 
22. Johnston, B.F., Mellor, J.W. 1961. The role of agriculture in economic development. The American Economic Review, Vol. 51(4), pp. 566-593.

23. Khan, M.H. 2001. Agricultural taxation in developing countries: a survey of issues and policy. Agricultural Economics, Vol. 24(3), pp. 315-328. https://doi.org/10.1111/j.1574-0862.2001.tb00033.x

24. Krenek, A., Schratzenstaller, M. 2017. Sustainability-oriented Future EU Funding: A European Net Wealth Tax. Available at http://www.diva-portal.org/smash/get/diva2:1112261/FULLTEXT01.pdf (Accessed on 17/02/2018).

25. Lamb, G. 1994. Community supported agriculture. Threefold Review, Vol. 11, pp. 39-43.

26. Leibus, I., Irmeja, A. 2014. Tax payments of agricultural sector in Latvia. Economic Science for Rural Development, Vol. 33, pp. $132-141$.

27. Myles, G.D. 2000. Taxation and economic growth. Fiscal studies, Vol. 21(1), pp. 141-168. https://doi.org/10.1111/j.1475$\underline{5890.2000 . t b 00583 . x}$

28. Myles, G.D. 2009. Economic growth and the role of taxation-disaggregate data. OECD Economic Department Working Papers, (715). Available at http://people.exeter.ac.uk/gdmyles/papers/pdfs/OECDfin.pdf (Accessed on 06/10/2017).

29. Mukhtar, H., Nasim, A. 2016. Agricultural Taxation in Punjab: The Missing Billions (No. 01-16). Working Paper. Available at http://ideaspak.org/images/Publications/Fiscal-Federalism/Agricultural-Income-Tax-Punjab-Missing-Billions.pdf (accessed on 06/11/2017).

30. Murray, K., Oliver, R., Wyatt, S. 2014) Evaluation of taxation reform in the Pacific. Ministry of Foreign Affairs and Trade, Wellington. Available at https://www.mfat.govt.nz/assets/Uploads/final-sapare-taxation-report-from-2014.pdf (Accessed on 11/11/2017).

31. Nam, C.W., Parsche, R., Radulescu, D.M., Schöpe, M. 2007. Taxation of fertilizers, pesticides and energy use for agricultural production in selected EU countries. Environmental Policy and Governance, Vol. 17(4), pp. $267-284$. https://doi.org/10.1002/eet.444

32. Novosinskiene, A. 2013. Lithuanian tax system evaluation in the fiscal tax function aspect. Zemes ukio mokslai, Vol. 20(3), pp. 222-229.

33. Raj, K. 1973. Direct taxation of agriculture. Indian Economic Review, Vol. 8(1), pp. 1-15.

34. Ronge, E., Wanjala, B., Njeru, J., Ojwang'i, D. 2005. Implicit Taxation of the Agricultural Sector in Kenya (No. 52). KIPPRA Discussion Paper. Available at https://s3.amazonaws.com/academia.edu.documents/8654698/dp52.pdf?AWSAccessKeyId=AKIAIWOWYYGZ2Y53UL3A\&E xpires $=1510418640 \&$ Signature $=$ KLysBikYTU3P9ppeS4uWgaxGo5o\%3D\&response-contentdisposition=inline\%3B\%20filename\%3DImplicit_Taxation_of_the_Agricultural_Se.pdf (Accessed on 11/11/2017).

35. OECD. (2018). Countries must strengthen tax systems to meet Sustainable Development Goals. Available at http://www.oecd.org/tax/countries-must-strengthen-tax-systems-to-meet-sustainable-development-goals.htm (accessed on 17/02/2018).

36. Schratzenstaller, M. 2016. Sustainable tax policy beyond the tax ratio for the EU as core element of a "Fiscal Union". Toward a Genuine Economic and Monetary Union. Vienna: Oesterreichische Nationalbank, pp. 141-157. Available at https://www.oenb.at/dam/jcr:0d3362b4-d200-48aa-92eac414445e2745/schratzenstaller_sustainable\%20tax\%20policy\%20beyond\%20the \%20tax\%20ratio\%20in\%20the \%20eu $\% 20$ as $\% 2$ 0core\%20element\%20of\%20a\%20'fiscal\%20union'_paper.pdf (Accessed on 11/11/2017).

37. Schratzenstaller, M. 2015. Sustainable tax policy. Revue de l'OFCE, Vol. (5), pp. 57-77. https://doi.org/10.3917/reof.141.0057

38. Skea, J., Nishioka, S. 2008. Policies and practices for a low-carbon society. Climate policy, 8 (2008), S5-S16. Available at http://www.tandfonline.com/doi/pdf/10.3763/cpol.2008.0487 (Accessed on 11/11/2017).

39. Stahel, W. R. 2011. The virtuous circle? Sustainable economics and taxation in a time of austerity. The Chartered Insurance 63.

Available

https://www.researchgate.net/profile/Walter_Stahel/publication/243688172_The_service_economy_Wealth_without_resource_c onsumption'/links/5472f9630cf2d67fc035d52e.pdf (Accessed on 06/11/2017).

40. Stahel, W.R. 2013. Policy for material efficiency_-sustainable taxation as a departure from the throwaway society. Phil. Trans. R. Soc. A, 371(1986), 20110567. https://doi.org/10.1098/rsta.2011.0567

41. Stancil, J. 2013. A model for sustainability taxation. Mustang Journal of Accounting \& Finance, 3. Available at http://www.themagicdad.com/MJAF/v3 MJAF 2013 forwebsite.pdf\#page=91 (Accessed on 11/11/2017).

42. Vanclay, F. 2004) Social principles for agricultural extension to assist in the promotion of natural resource management. Australian Journal of Experimental Agriculture, Vol. 44(3), pp. 213-222. https://doi.org/10.1071/EA02139

43. Veen, H., Meulen, H., Bommel, K., Doorneweert, B. 2007. Exploring agricultural taxation in Europe. Agricultural Economics Research Institute, Haga. Available at http://library.wur.nl/WebQuery/wurpubs/fulltext/23200 (Accessed on 06/11/2017).

44. Zhong, C., Turvey, C., Zhang, J., Xu, C. 2011) Does taxation have real effects on agricultural output? Theory and empirical evidence from China. Journal of Economic Policy Reform, Vol. 14(3), pp. $227-242$. https://doi.org/10.1080/17487870.2011.575105 